ARTICULO DE INVESTIGACION

\title{
Strength properties and natural durability of Avocado (Persea americana Mill.) branch wood
}

\author{
Propiedades de resistencia y durabilidad natural de la \\ madera de ramas de aguacate (Persea americana Mill.)
}

\author{
F.J. Fuentes-Talavera1, J.A. Silva-Guzmán, R. Rodríguez-Anda, \\ M.G. Lomelí-Ramírez, R. Sanjuán-Dueñas y H.G. Richter
}

\begin{abstract}
This paper reports on mechanical properties and natural durability of avocado branch wood (Persea americana Mill.) with the objectives of providing a reliable property profile and to promote the rational use of this abundant yet largely neglected natural resource. The mechanical properties (static bending, compression, shear, impact bending) and hardness were determined in accordance with European standards (CEN). Natural durability was assessed according to the European standard EN 350-1 (agar block test) using the white rot fungi Trametes versicolor and Phanerochaete chrysosporium, and the brown rot fungus Postia placenta. Avocado trees yield a low to medium density $\left(0,44-0,54-0,64 \mathrm{~g} / \mathrm{cm}^{3}\right.$ at $\left.12 \% \mathrm{mc}\right)$ branch wood with below average strength under static bending, compression and tension parallel to the grain and average values for longitudinal shear, impact bending and hardness. The wood is rated non-resistant (class 5 according to EN 350-1) and thus is not suitable for exterior applications unless treated. Considering its property profile and the small dimensions available, avocado wood is recommended for general carpentry, furniture, interior paneling, glue-boards for closets and cabinets, and glue-lams for indoor framework.
\end{abstract}

KEY WORDS:

Persea americana, Trametes versicolor, Phanerochaete chrysosporium, Postia placenta, branch wood, density, strength properties, natural durability, uses.

\section{RESUMEN}

Este artículo presenta información sobre las propiedades mecánicas y la durabilidad natural de madera de las ramas de aguacate (Persea americana Mill.) con los objetivos de proporcionar un perfil de propiedades confiable y promover el uso racional de este recurso natural abundante pero en gran parte abandonado. Las propiedades mecánicas (flexión estática, compresión, cortante, resistencia al impacto) y dureza se determinan de conformidad con las normas europeas (CEN). La durabilidad natural se evaluó de acuerdo con la norma europea EN 350-1 (prueba de bloque de agar) utilizando los hongos de pudrición blanca Trametes versicolor y de hongo de pudrición parda Phanerochaete chrysosporium. Árboles de aguacate producen una madera de rama de baja a mediana densidad $\left(0,44-0,54-0,64 \mathrm{~g} / \mathrm{cm}^{3}\right.$ en $\left.12 \% \mathrm{mc}\right)$ con valores medios a bajos de flexión estática, compresión y tensión paralela a la fibra y valores medios de resistencia al cortante longitudinal, impacto y dureza. La madera se considera como no resistente (clase 5 según EN 350-1) y por lo tanto no es apta para aplicaciones en el exterior a menos que esté tratada. Teniendo en cuenta su perfil de propiedades y las pequeñas dimensiones disponibles, la madera de aguacate se recomienda para carpintería 
general, muebles, decoración interior, placas encoladas para armarios y archivadores y madera laminada para usos interiores.

KEY WORDS:

Persea americana, Trametes versicolor, Phanerochaete chrysosporium, Postia placenta, branch wood, density, strength properties, natural durability, uses.

\section{INTRODUCTION}

In Mexico, approximately 101882 ha are planted with avocado trees for fruit production. About $89 \%$ pertain to the commercially most important variety "Hass", the remaining $11 \%$ to other varieties, including the wild or "criollo" form (SIACON, 2006). Thanks to this large and growing plantation area, Mexico has become the major avocado producer worldwide with slightly over one million metric tons of fruit in 2003 (FAO, 2006) of which about $75 \%$ are consumed in the country and $25 \%$ (slightly over US\$ 400 million) exported, mainly to the United States of America (Del Castillo, 2008).

The largest area, 86538 ha or $84 \%$ of the total area of avocado orchards planted in Mexico and responsible for $25 \%$ of worldwide fruit production (Del Castillo, 2008), is located in the state of Michoacan, mainly of the Hass variety (95\%), with a great diversity as regards age, productivity and phytosanitary conditions. These plantations are frequently subject to thinning, coppicing, felling and replanting operations, which yield a considerable volume of wood that is largely moved to the plantation boundaries and burned or left to rot.

There are no statistical data that would allow a reliable calculation of the wood volume per hectare/year available from such coppicing and clearing operations in avocado plantations. However, taking an avocado orchard in Jujucato,
Michoacán, as a fairly typical example for size (4 ha) and number of trees (125/ha) as well as tree age (from 14 to 30 years) and sound coppicing practices, the potentially available volume of wood can be estimated by extrapolation as follows: Assuming that coppicing of a tree yields 12 (Silva, 2009, personal communication) small logs of $1 \mathrm{~m}$ in length and 20 to $25 \mathrm{~cm}$ in diameter $(0,38$ to $0,59 \mathrm{~m}^{3}$ per tree) and $10 \%$ of the trees/ha are subject to coppicing each year, the yield is 4,75 to $7,36 \mathrm{~m}^{3} /$ ha/year. Further assuming that about $50 \%$ (slightly over $50000 \mathrm{ha}$ ) of the productive avocado plantations in Mexico are subjected to such cleaning operations, the total wood volume expected per year could amount to between 237500 to $368000 \mathrm{~m}^{3}$.

The rational utilization of this byproduct of avocado fruit production could be greatly enhanced by providing reliable scientific information about the timber's biological and technological properties as well as appropriate end uses.

Avocado wood is easy to work in all machining operations and finishes smoothly (Martínez y Martínez, 1996). Fuzzy grain may occur due to the presence of tension wood often present in branch wood. Based on its tangential and radial shrinkage values the wood is rated moderately stable and movement in service is expected to be low with little risk of deformation of manufactured goods within the relative humidity range (35\% to $85 \% \mathrm{RH}$ ) to which wood is usually exposed in service (Fuentes et al., 2002). Avocado wood is also considered a suitable raw material for pulping and papermaking. Paper produced from this material has physical and mechanical properties similar to that made with eucalypt (Eucalyptus grandis) fibers (Vargas et al., 2006).

As regards strength properties of avocado wood, there is very little informa- 
tion available from literature. Echenique y Plumptre (1990) and also the Prospect (1997) database report on strength properties in a very general way without giving numerical values for means and variation. The same authors classify Persea americana heartwood as not durable or class IV according to EN 350-2 (CEN, 1994).

The objective of this study is to provide the potential users of this raw material with reliable numerical data on its elastic and strength properties in order to facilitate decisions as to where and in what form avocado wood from coppicing operations can be put to appropriate use. Further, the question whether this material consists entirely of sapwood (generally rated perishable $=$ class $\mathrm{V}$ ) or contains appreciable portions of heartwood (class IV) was analyzed by means of macro and microscopic observation (presence vs. absence of tyloses) and a bioassay to evaluate its resistance against decay producing white and brown rot fungi.

\section{MATERIAL AND METHODS}

Logs, approximately $100 \mathrm{~cm}$ in length and 20 to $25 \mathrm{~cm}$ in diameter, were cut from a main branch of each of 10 trees coppiced during a clearing operation at an avocado orchard in Jujucato, Michoacán. Branch wood constitutes the only raw material commonly available from this operation whereas the coppiced stump is usually left in place for resprouting from stem buds. The trees were between 14 and 17 years old and had reached a total height of about $12 \mathrm{~m}$. A two-inch thick disk was cut from each log for observations of wood structure and natural durability bioassays. The remainder was sawn into $50 \mathrm{~mm}$ thick radial boards, which were stacked and air-dried to equilibrium moisture content of approximately $10 \%$. From the dry boards test specimens were prepared in the dimensions required by the standards (table 1) employed for static bending, compression parallel to the grain, tension parallel to the grain, longitudinal shear, impact bending and hard-

Table 1 Standards employed for determining physical and mechanical wood properties (DIN, 1979).

DIN 52182 Density

DIN 52185 Compression parallel to the grain

DIN 52186 Static bending

DIN 52187 Shear parallel to the grain

DIN 52188 Tension parallel to the grain

DIN 52189 Impact bending

DIN C 3011 Hardness BRINELL (mathematical conversion to JANKA hardness according to the equation

hardness $_{\text {JANKA }}=\left(\right.$ hardness $_{\text {BRINELL-7.3) }} / 3.1($ Schwab, 1990) 
ness. Since the test specimens could not be conditioned in standard climate $\left(20^{\circ} \mathrm{C}\right.$, $65 \% \mathrm{RH}$ ) prior to testing, the test results for MOR and MOE in bending, compression and tension as well as density were adjusted to $12 \% \mathrm{mc}$ in accordance with ASTM D-2915-94 (1998) and ISO 3131 (1975) standards, respectively.

The natural decay resistance of $P$. americana to decay fungi was evaluated with disks cut from five of the ten harvested logs according to the procedures described in the European standard EN 350-1 (CEN 1994). Specimen size was reduced to $2,5 \times 2,5 \times 1,0 \mathrm{~cm}^{3}$ to accommodate more specimens per disk than would have been possible with the larger dimensions $\left(2,5 \times 1,5 \times 5,0 \mathrm{~cm}^{3}\right)$ suggested in the standard. All specimens were oven-dried at $102{ }^{\circ} \mathrm{C}$ to determine the initial dry weight (W1). The dry specimens were subsequently reconditioned the moisture saturated condition and steam-sterilized $\left(15 \mathrm{~min} / 121^{\circ} \mathrm{C}\right)$. The test fungi used were Postia placenta (Fries) M. Larsen \& Lombard (brown rot); Phanerochaete chrysosporium Burdsall and Trametes versicolor (L. Fries) Pilát (white rot). The fungi were grown on malt extract agar (MEA, 3,6 \%) before inoculation. Ten replicates per fungus were conducted. Glass jars $(225 \mathrm{ml})$ with $40 \mathrm{ml}$ of malt extract agar (MEA, 3,6 \%) were sterilized $\left(30 \mathrm{~min} / 121^{\circ} \mathrm{C}\right.$ ) and the fungal inoculum deposited on the MEA surface. The glass jars were incubated $\left(27^{\circ} \mathrm{C} / 70 \% \mathrm{RH}\right)$ until the mycelium completely covered the agar surface. The test specimens were then placed in the jars on two small capillary tubes (diameter $1,5 \mathrm{~mm}$ ) to separate the agar from the wood surface. Ten noninoculated specimens served as controls in both test series. Specimens of the nondurable wood of Mexican aile (Alnus acuminata) were used as reference to verify the respective white and brown rot fungi's capacity of degrading wood.
The jars with the test specimens were incubated in a decay chamber at 27 ${ }^{\circ} \mathrm{C}$ and $70 \% \mathrm{RH}$ for 12 to 16 weeks. At the end of that period the specimens were taken out of the jars, cleaned carefully, weighed and subsequently oven-dried to determine the final dry weight (W2). Weight loss (WL) was calculated as follows:

Statistical data analyses were conducted with the software package Statgraphics 5.0, making use of the simple (ANOVA) analysis of variance offered by the package.

\section{RESULTS AND DISCUSSION}

\section{Density}

The histogram presented in figure 1 depicts the density frequency distribution of all test specimens $(\mathrm{N}=144)$. Normal density (adjusted to $12 \% \mathrm{mc}$ ) shows a normal distribution (USDA Forest Service, 1999) within a range from 0,45 to 0,63 $\mathrm{g} / \mathrm{cm}^{3}$, an overall mean of $0,54 \mathrm{~g} / \mathrm{cm}^{3}$ and a coefficient of variation of $6,6 \%$.

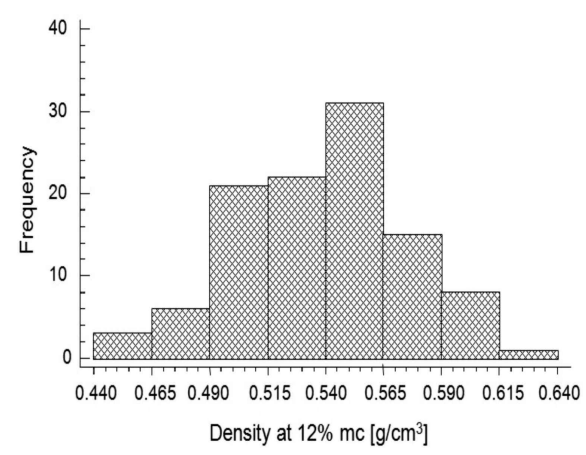

Figure 1 Density distribution of Persea americana branch wood 
Table 2. Selected elastic and strength properties and density adjusted to $12 \% \mathrm{mc}$ of Persea americana branch wood featuring the number of specimens per test $(\mathrm{N})$; mean, minimum and maximum values; coefficient of variation (CV).

\begin{tabular}{lcccc}
\hline & \multicolumn{2}{c}{ Static bending $(\mathrm{N}=33)$} & & \\
& Mean & Min & Max & CV [\%] \\
MOR $\left[\mathrm{N} / \mathrm{mm}^{2}\right]$ & 73 & 60 & 92 & 11 \\
MOE $\left[\mathrm{N} / \mathrm{mm}^{2}\right]$ & 5937 & 4328 & 8235 & 17 \\
Density at $12 \% \mathrm{mc}\left[\mathrm{g} / \mathrm{cm}^{3}\right]$ & 0,54 & 0,47 & 0,60 & 6
\end{tabular}

Compression parallel to the grain $(\mathrm{N}=25)$

MOR [N/mm²]

Mean Min

MOE $\left[\mathrm{N} / \mathrm{mm}^{2}\right]$

35

23

Max CV [\%]

Density at $12 \% \mathrm{mc}\left[\mathrm{g} / \mathrm{cm}^{3}\right]$

5548

3367

47

15

0,45

0,44

7611

20

$0,51 \quad 8$

Tension parallel to the grain $(\mathrm{N}=23)$

MOR [N/mm²]

MOE $\left[\mathrm{N} / \mathrm{mm}^{2}\right]$

Shear strength [N/mm²]

Density at $12 \% \mathrm{mc}\left[\mathrm{g} / \mathrm{cm}^{3}\right]$

Impact bending strength $\left[\mathrm{kJ} / \mathrm{m}^{2}\right]$

Density at $12 \% \mathrm{mc}\left[\mathrm{g} / \mathrm{cm}^{3}\right]$
Mean

63

6679
Min

33

4163

Max

CV [\%]

83

15

11056

20

Shear parallel to the grain $(N=13)$

$\begin{array}{cccc}\text { Mean } & \text { Min } & \text { Max } & \text { CV [\%] } \\ 9 & 7 & 13 & 21 \\ 0,58 & 0,55 & 0,65 & 4,5\end{array}$

Impact bending $(\mathrm{N}=25)$

$\begin{array}{cccc}\text { Mean } & \text { Min } & \text { Max } & \text { CV [\%] } \\ 42 & 25 & 63 & 23 \\ 0,54 & 0,49 & 0,62 & 6\end{array}$

Hardness BRINELL/JANKA1 ( $\mathrm{N}=25)$

1BRINELL values / mathematically converted to JANKA hardness (Schwab, 1990) 


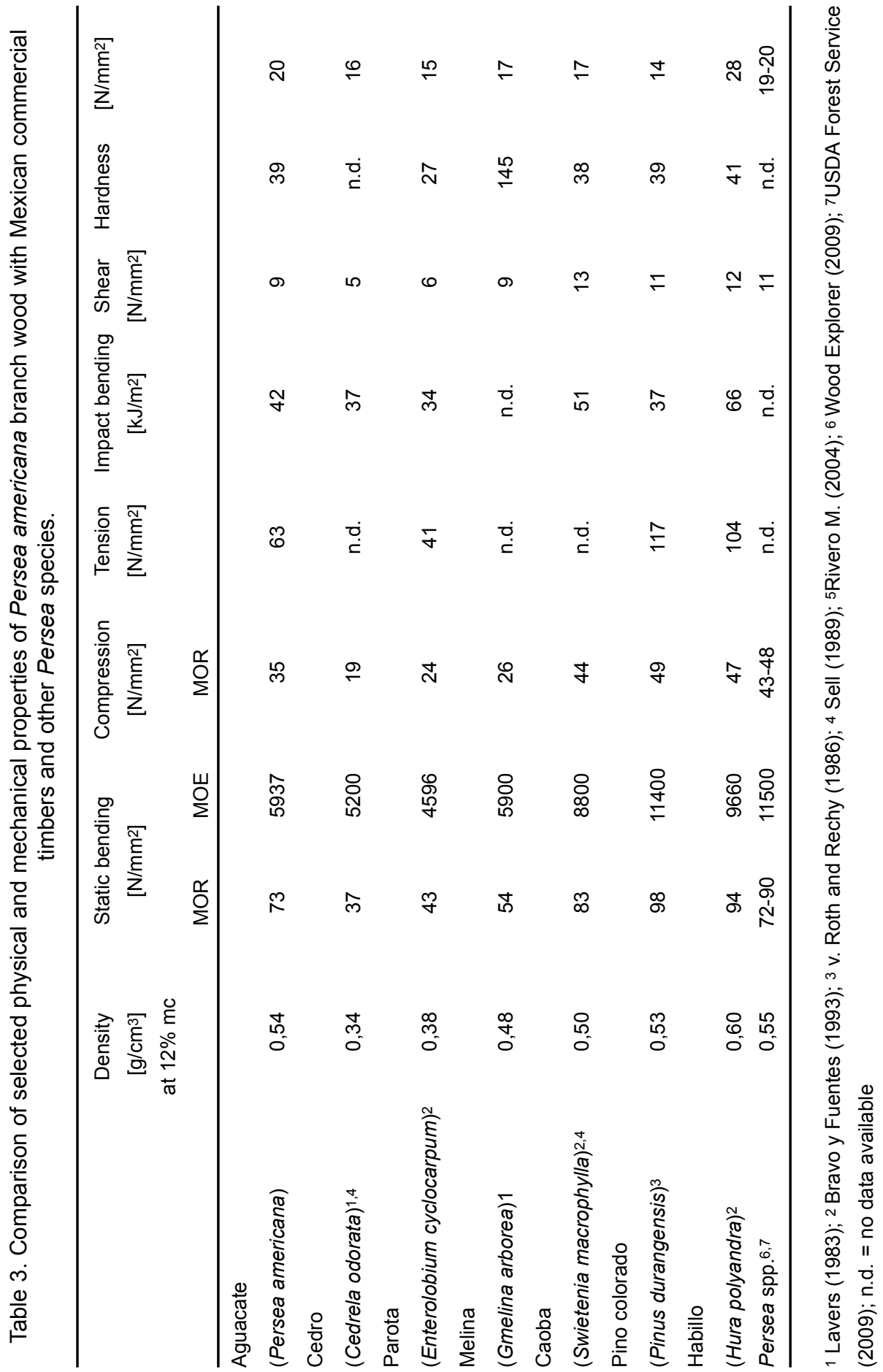


Compared to some of the more common structural timbers in Mexico such as pino colorado (Pinus durangensis) (v. Roth \& Rechy, 1986), habillo (Hura polyandra) (Bravo \& Fuentes, 1993), caoba (Swietenia macrophylla) (Richter \& Oelker, 2002; Sell, 1989) and other Persea species (Wood Explorer, 2009; USDA Forest Service, 2009) in the same density range, avocado branch wood is below average in bending, compression and tension. However, the values obtained compare favorably with lighter weight nonstructural timbers such as melina (Gmelina arborea) (Obregón, 2009; Rojas et al., 2004; Fujiwara et al., 1996), cedro (Cedrela odorata) (Escobar et al., 1993; CIRAD-Forêt, 2009) and parota (Enterolobium cyclocarpum) (Bravo \& Fuentes, 1993) (Table 3).

As for impact bending, shear and hardness, avocado branch wood possesses properties commensurate with its density comparable to those of the structural timbers listed in table 3 . The dispersion of the values encountered and reflected in the coefficients of variation (CV; table 2), is of an acceptable magnitude and somewhat below the levels reported by the USDA Forest Service (1999) for some mechanical properties of clear wood. Taking into account that the studied material is branch wood, a higher variability of elastic and strength properties would have to be expected according to Bowyer et al. (2003).

\section{Wood structure and natural durability}

General macroscopic and microscopic features of Persea americana wood were reported earlier (Silva et al., 1999). In the context of the present study, observations focused on the presence or absence of tyloses in the investigated material. The results, obtained from radial strips extending from pith to bark, were negative throughout, i.e. no tyloses were detected. Since the formation of tyloses in heartwood is a mandatory character of all taxa pertaining to the family of Lauraceae (Richter, 1981), the lack of this feature indicates that the material obtained from coppicing operations in avocado orchards is essentially all sapwood.

This observation was confirmed by the accompanying bioassay in which the wood under study was tested under exposure to decay-producing fungi according to the European standard EN 350-1 (CEN, 1994). The mass losses recorded for the white rot fungi Trametes versicolor and Phanerochaete chrysosporium was $61 \%$ and $46 \%$, respectively, that for the brown rot fungus Postia placenta 32\% (Table 4). These mass losses are of the same magnitude as those recorded for the aile (Alnus acuminata) reference wood considered highly susceptible to fungal decay (Lomelí \& Fuentes, 1997; Sachsse \& Schulte, 1991). Accordingly, since mass losses are larger than $30 \%$ for all three fungi, the studied material is rated perishable (class $\mathrm{V}$ according to DIN-EN 350-1; CEN, 1994) and is expected to have a short service life under exterior and other decay-producing conditions unless preservative treated.

\section{Analysis of possible end uses}

In light of its fairly high hygroscopicity (Fuentes et al., 2002) and susceptibility to wood staining and decaying fungi, avocado branch wood generated from coppicing operations is unsuitable for exterior use unless properly protected.

Traditional uses of avocado wood include, for instance, sawn timber, firewood, turned articles, structural parts of guitar bodies (Rogel, 1982), light construction, flooring, furniture, general carpentry works and rotary veneer for 
plywood (Chudnoff, 1984). For the state of Michoacán, Guridi (1980) mentions wooden elements used in the manufacture of violins and guitars, whereas Pennington \& Sarukhán (1998) refer to light construction and turned objects.

Some of these traditional uses can be confirmed, such as structural nonresonance elements for string instruments, turnery and furniture parts. On the other hand, to use avocado branch wood for structural members cannot be recommended for two reasons: a) its elastic and strength properties in bending, compression and tension are low and its load bearing capacity very limited; b) the dimensions (length, diameter) of the generally available material do not allow the manufacture of larger elements like beams, trusses and posts. Similarly, the low side hardness of avocado branch wood does not make it a commendable choice for flooring (parquet, solid wood and upper layer of prefab composites) as the wood surface is likely to deteriorate rapidly under the abrasive and compressive forces to which even light traffic floors are commonly subjected.
Low grade avocado branch wood can be converted into packaging materials (boxes, crates, etc.) or chipped for use in pulp and paper making (Vargas et al., 2006) and manufacture of wood composites (MDF, particle board). Given its good machining properties (Echenique \& Plumtre, 1990; Martínez \& Martínez, 1996), its moderate movement in service (Fuentes et al., 2002; USDA Forest Service, 1999) and ease of gluing (Wood Explorer, 2009), good quality avocado branch wood has considerable utilization potential. It would be a natural choice to be adopted by the Mexican furniture industry as a substitute for costly imports from South and North America for the production of home furnishing items, chairs, small radio-stereo-TV cabinets, kitchen cabinets, etc. The manufacture of solid wood composites such as glue boards and gluelaminated scantlings would greatly increase the profitable utilization of the available raw material for value-added products such as fronts and sides of closets, larger cabinets, shelves, partitioning walls, interior paneling, door frames, etc. The required technology for primary conversion of small logs, drying, jointing

Table 4. Weight losses of Persea americana branch wood and Alnus acuminata (reference species) after a 12 to 16 week exposure to white rot (Trametes versicolor, Phanerochaete chrysosporium) and brown rot (Postia placenta) decay fungi.

\begin{tabular}{lccccc}
\hline & Weight loss [\%] & T. versicolor 1 & P. chrysosporium & P. placenta & Controls \\
\hline \multirow{2}{*}{ Persea americana } & Mean & 60.45 & 45.22 & 32.53 & 0.43 \\
& Min & 58.74 & 44.04 & 31.80 & 0.40 \\
& Max & 61.39 & 46.41 & 33.51 & 0.45 \\
& CV & 1.82 & 1.96 & 1.71 & 5.2 \\
Alnus acuminata & Mean & 60.91 & 45.57 & 36.10 & - \\
(reference) & Min & 58.49 & 43.91 & 35.40 & - \\
& Max & 63.19 & 46.97 & 37.46 & - \\
& CV & 1.99 & 2.50 & 2.06 & - \\
\hline
\end{tabular}

112 week exposure time; for the other fungi and controls the exposure time was 16 weeks 
and gluing is available in the market and the ensuing investments will no doubt pay off in the long run as has been proven with other wood byproducts from agricultural crops such as the sustainable, eco-friendly rubber wood (Hevea brasiliensis) emanating from latex producing plantations in Southeast Asia (Hong, 1996).

\section{CONCLUSIONS}

Persea americana (avocado) branch wood possesses strength properties in the low to medium range which largely limits its utilization to non-structural applications. It is also highly susceptible to biological degradation by decay fungi and should therefore be employed only under conditions protected from drastic moisture changes in order to guarantee a reasonable in-service performance.

By means of an adequate conversion technology, i.e. reduction and reconstitution to larger dimensions by appropriate jointing and gluing techniques, the raw material has considerable potential for general carpentry and, particularly, the Mexican furniture industry as a reasonable alternative for exotic timbers imported at high cost from other regions of the globe.

\section{ACKNOWLEDGEMENTS}

The authors are grateful to Ms Olaya Guzmán, owner of the avocado orchard at the village of Jujucato, for donating the raw material used in this study and providing the necessary infrastructure for its acquisition.

\section{REFERENCES}

ASTM D 2915-94. 1998. Standard practice for Evaluating Allowable Properties for
Grades of Structural Lumber. Annual Book of ASTM Standards. Section 4. Construction. Volume 04.10 Wood:397-408.

Bowyer J.L., R. Shmulsky y J.G. Haygreen. 2003. Forest Products and Wood Science. lowa State Press, $4^{\text {th }}$ edition. lowa, U.S.A. 554 p.

Bravo G., L.R. y F.J. Fuentes T. 1993. Composición química y propiedades de algunas maderas mexicanas. Memorias del I Congreso Mexicano sobre Recursos Forestales. UAAN. Saltillo, Coahuila, p. 89.

Chudnoff, M. 1984. Tropical Timbers of the World. USDA Forest Service, Agriculture Handbook \#607. Forest Products Laboratory, Madison, WI. $464 \mathrm{p}$.

CEN - European Committee for Standardization. 1994. Standard EN 350-1/2. Durability of wood and wood-based products - Natural durability of solid wood. Part 1: Guide to the principles of testing and classification of the natural durability of wood. Part 2: Guide to natural durability and treatability of selected wood species of importance in Europe.

CIRAD-Forêt 2009: Fiches techniques. TROPIX 6.0. CIRAD Forestry Department, Montpellier, France, online at http://tropix.cirad.fr/index.htm. Consulted June 2009.

Del Castillo, A. 2008. Michoacán: la fiebre del "oro verde". Nota periodística publicada en el periódico Público, Guadalajara, año 12, No. 4088, p. 6-8.

Echenique-Manrique R. y R.A. Plumptre. 1990. A guide to the use of Mexican and Belizean timbers. Oxford Forestry Institute, Department of Plant 
Sciences. University of Oxford. Oxford, England. 196 p.

Escobar, C.O., J.R. Rodríguez y J.A. Correa. 1993. Las maderas en Colombia -fichas técnicas. Universidad Nacional de Colombia- SENA. Available online at http://www.unalmed.edu.co/ Ipforest/html/fichastecnicas.html. Consulted June 2009.

DIN. 1979. Taschenbuch der Holznormen No.31. DIN Deutsches Institut für Normung e.V. Beuth Verlag $\mathrm{GmbH}$, Berlin und Köln. 203 p.

FAO. 2006. Major food and agricultural commodities and producers. Databases FAOSTAT, online at: http://www.fao.org/es/ess/top/comm odity.html?lang=en\&item $=572$ \&year $=2005$. Consulted June 2009.

Fuentes T., F.J., J.A. Silva G., M.G. Lomelí R., H.G. Richter y R. Sanjuán D. 2002. Comportamiento higroscópico de la madera de Persea americana var. guatemalensis Mill. (Hass). Revista Chapingo. Serie Ciencias Forestales y del Ambiente 8(1):49-56.

Fujiwara, T., T. Fujii, T. Shiibayashi, T. Suzuki y Y. Hayashi. 1996. Construction of Database on Properties of Woods from Southeast Asia. The International Conference on Forest Products, Bangkok, Thailand, 17-22 December, online at: http://www2.ffpri.affrc. go.jp/fdb/esawoodq/wood.html. Consulted June 2009.

Guridi G., L.I. 1980. La madera en las artesanías del estado de Michoacán. Bol. Div. No.50, Inst. Nac. Invest. For. México, D.F. 132 p.

Hong, L. T. 1996. Rubberwood utilization - a success story. Paper presented at the 20th IUFRO World Congress, Tampere,
Finland, online at http://www.metla.fi/i ufro95abs/rsp19.htm. Consulted June 2009.

ISO 3131. 1975. Wood. Determination of density for physical and mechanical tests. International Standard Organization, Geneva, Switzerland. 2 p.

Lavers, G.M. 1983. The strength properties of timber. Building Research Establishment Report, 3rd edition. 60 p.

Lomelí R., M.G. y F.J. Fuentes T. 1997. Biodeterioro de la madera de aile y aguacate por los hongos xilófagos. Memoria VI. Congreso Nacional de Micología, Jornadas Científicas. Tapachula, Chiapas, México. p. 59-60.

Martínez P., C.E. y J.L. Martínez C. 1996. Características de cepillado y lijado de 33 especies de madera. Madera y Bosques 2(1):11-27.

Obregón S., C. 2009. Gmelina arborea, versatilidad, renovación y productividad sostenible para el futuro. Revista El Mueble y la Madera, Bogotá, Colombia. Serie "Especies", edición especial. p. 14-20.

Pennington, T.D. y J. Sarukhán. 1998. Árboles tropicales de México. Ediciones Científicas Universitarias. Serie Texto Científico Universitario. Universidad Nacional Autónoma de México y Fondo de Cultura Económica. $521 \mathrm{p}$.

Prospect. 1997. The Wood Database, Version 2.1 en CD ROM, Forestry Oxford Institute. University of Oxford, Oxford, England.

Richter, H.G. 1981. Die Anatomie des Sekundären Xylems und der Rinde der Lauraceae. Abhandl. Naturw. Verein, Hamburg, No. 25, 152 S. 
Richter, H.G., M. Oelker y G. Kraemer 2002. macroHoLzdata Datenbank Computer-gestützte makroskopische Holzartenbestimmung sowie Informationen zu Eigenschaften und Verwendung von Nutzhölzern. CD-ROM, Holzfachschule Bad Wildungen, Eigenverlag.

Rogel G., Ma. de los A. 1982. Estudio anatómico de 6 especies tropicales. Boletín Técnico. Instituto Nacional de Investigaciones Forestales 89:37-41.

Rojas R., F., D. Arias A., R. Moya R., A. Meza M., O. Murillo G. y M. Arguedas G. 2004. Manual para productores de melina (Gmelina arborea) en Costa Rica. Cartago, Costa Rica. 314 p. Available online at (www.fonafifo. com/text_files/proyectos/Manual\%2 OProd\%20Melina.pdf). Consulted June 2009.

Roth V., W. y M. Rechy, 1986. Important structural properties of Pinus durangensis Martínez. Holz als Roh- und Werkstoff 44:41-46.

Sachsse, H. y A. Schulte. 1991. Wood properties of the Andes alder (Alnus acuminata). Forstarchiv 62(5):196-199.

Schwab, E. 1990. Die Härte von Laubhölzern für die Parkettherstellung. Holz als Roh- und Werkstoff 48:47-51.

Sell, J. 1989. Eigenschaften und Kenngrö,en von Holzarten. Baufachverlag Lignum. $51 \mathrm{p}$.
SIACON. 2006. Anuario estadístico de la producción agrícola. 2004. Sistema de Información Agropecuaria de Consulta. Available online at: http://w3.siap. sagarpa.gob.mx:8080/siiap_apb/. Consulted June 2009.

Silva G., J. A., F.J. Fuentes T., H.G. Richter, G. Ángeles A. y R. Sanjuán D. 1999. Estructura de la madera de Persea americana var. guatemalensis Mill. (Hass.). Madera y Bosques 5(1):53-59.

USDA Forest Service. 1999. Wood handbook: Wood as an engineering material. USDA Forest Service. Forest Products Laboratory General Technical Report FPL-GTR-113.

USDA Forest Service. 2009. Technology Transfer Fact Sheets. Center for Wood Anatomy Research. Forest Products Laboratory, Madison/WI, USA, online at http://www2.fpl.fs.fed.us/. Consulted June 2009.

Vargas R., J., R. Sanjuán D., J.A. Silva G., J. Rivera P., F.J. Fuentes T. y H.G. Richter. 2006. Properties of bleached pulp sheets of avocado wood (Persea americana Mill.) pulped by kraft and soda processes. Madera y Bosques. 12(1):29-36.

Wood Explorer. 2009. Persea lingue fact sheet, online at: http://www.thewoodmarket.com/temp/we887.html Consulted June 2009 